\title{
KOMU I DO CZEGO POTRZEBNE BYŁY W XVI W. SUMARIUSZE PODATKOWE? O NARODZINACH PLANOWANIA BUDŻETOWEGO WE WCZESNONOWOŻYTNYM KRÓLESTWIE POLSKIM
}

W literaturze przedmiotu utrwaliło się przekonanie, że przeznaczeniem szesnastowiecznych sumariuszy podatkowych było podsumowanie rejestru poborowego i $\mathrm{w}$ efekcie rozliczenie się poborcy $\mathrm{z}$ podskarbim z przeprowadzonego poboru1. Opiera się ono na autorytecie Adolfa Pawińskiego, wydawcy Źródet dziejowych. W swym studium o skarbowości czasów Stefana Batorego wyraził on bowiem opinię, że sumariusze na końcach rejestrów pozwalały na sporządzenie budżetu minionego roku, a więc ich przeznaczeniem było podsumowywanie dochodów podatkowych ${ }^{2}$. Także wcześniej w tej samej pracy stwierdził on, że poborcy rozliczali się przed sejmem z zebranych podatków właśnie w oparciu o rejestry poborowe i umieszczane na ich końcach sumariusze $^{3}$. Wiele lat później w podobnym duchu wypowiedziała się Irena Gieysztorowa. Badaczka ta prawdopodobnie najwięcej uwagi ze wszystkich historyków (od czasów badań prowadzonych przez Pawińskiego) poświęciła sumariuszom poborowym. Jej zdaniem były one dokumentacją powstałą w efekcie konieczności rozliczania się poborców z zebranych kwot podatków ${ }^{4}$. Celem tego artykułu jest przedstawienie alternatywnej interpretacji genezy sumariuszy podatkowych.

$\mathrm{Z}$ pozoru wyjaśnienia pojawienia się sumariuszy przedstawione w dotychczasowej literaturze wydaja się absolutnie logiczne. Podstawą

${ }^{1}$ T. Szulc, Skarbowość polska w latach 1492-1587 $w$ historiografii, w: Studia z Dziejów Państwa i Prawa Polskiego, t. 8, Lublin-Łódź 2003, s. 20.

${ }^{2}$ A. Pawiński, Źródła dziejowe, t. 8: Skarbowość w Polsce i jej dzieje za Stefana Batorego, Warszawa 1881, s. 304.

3 Tamże, s. 298.

${ }^{4}$ I. Gieysztorowa, Zmiany gospodarczo-spoteczne wsi mazowieckiej $w$ XVI wieku $w$ świetle sumariuszy poborowych, „Przegląd Historyczny” 49, 1958, z. 2, s. 237. 
do wybierania podatków były uniwersały sejmowe, które ustalały podstawę opodatkowania i stawki podatku do zapłacenia. W efekcie poboru przeprowadzonego $\mathrm{w}$ oparciu o uniwersał poborowy powstawały rejestry podatkowe, a sumariusze wydają się całkowicie naturalnym elementem zamykającym taki rejestr: niezbędnym dla funkcjonowania administracji podsumowaniem ciagu danych liczbowych. Sporządzanie sumariuszy wydaje się czymś całkowicie naturalnym dla badaczy przeszłości wywodzących się z „epoki statystycznej” (XIX czy XX w.). Dla ludzi początków epoki nowożytnej (a więc czasów „przedstatystycznych”) ich obecność nie musiała być jednak taka oczywista.

Aby zweryfikować zasadność opinii łączącej sumariusze poborowe ze sprawozdawczością sejmowa, należy w pierwszej kolejności sięgnąć do źródeł normatywnych (przede wszystkim uniwersałów poborowych), regulujących zasady działania aparatu skarbowego w XVI w. Zachowane do dziś i opublikowane w wydawnictwie Volumina Constitutionum uchwały poborowe, jak i inne dokumenty powstałe w efekcie obrad sejmowych dla najwcześniejszego okresu, lat 1493-1520, nie zawierają żadnych nakazów sporządzania i dołączania do rejestrów poborowych sumariuszy. W poszczególnych uniwersałach pojawiają się jedynie informacje o obowiązku wzajemnego wystawiania kwitacji przez poborców i depozytariuszy w chwili przekazywania przez tych pierwszych pieniędzy tym drugim $^{5}$. Także ordynacja podatkowa z $1520 \mathrm{r}$. nie wspomina nic o sumariuszach, ale jedynie o kwitacjach ${ }^{6}$. Zachowany mandat królewski z 1496 r., ogłaszający pobór łanowego i powołujący poborcę dla ziemi łęczyckiej, wskazuje na ugruntowaną już w końcu XV w. praktykę wystawiania przez poborców kwitacji także płatnikom uiszczającym podatki ${ }^{7}$. Charakterystyczne jest przy tym, że regulacje dotyczące trybu rozliczania wpływów podatkowych przez poborców z podskarbimi zajmowały w tym okresie w uchwałach sejmowych minimalną ilość miejsca. Zasadniczą zmianę w tym względzie przyniósł dopiero uniwersał poborowy z 1527 r., w którym umieszczony został bardzo szczegółowy opis procedury zdawania przez poborców relacji z wykonania uchwał podatkowych. Oto jego najistotniejszy fragment:

Et in conventus particularibus, qui praecedent generalem regni conventum futurum, facient facereque tenebuntur rationem de pecuniis contributio-

${ }^{5}$ Volumina Constitutionum, t. 1: 1493-1549, cz. 1: 1493-1526, oprac. S. Grodziski, I. Dwornicka, W. Uruszczak, Warszawa 1996, s. 88-90, 135, 148-150.

${ }^{6}$ Tamże, s. 335-337.

${ }^{7}$ Volumina Constitutionum, t. 1, cz. 2: 1527-1549, oprac. S. Grodziski, I. Dwornicka, W. Uruszczak, Warszawa 2000, s. 315. 
num a se perceptis et expositis coram palatino, castellanis, dignitariis et officialibus palatinatus sui ac etiam coram uniwersa nobilitate, si eandem rationem audire voluerit, alias coram aliquot viris, quos eadem nobilitas de medio suo elegerit, et illo viro nobili, qui ad dispensandam publicam pecuniam cum palatino et ipsis exactoribus fuerit electus. Et eandem rationem suam veram esse comprobabunt hi ipsi exactores quietantiis, quas dabunt hominibus, contributiones ipsas solventibus, non autem regestris suis. Eas autem quietantias rectores parochialium ecclesiarum seu plebani de mandato dominorum episcoporum in civitatibus, oppidis et villis parochiarum suarum excribent fideliter et eas ad Ipsos dominos episcopos perferent. Domini autem episcopi transmittent illas ad conventus particulares, in quibus eadem ipsa ratio fieri per exactores debebit ad rationem exactorum melius comprobandum ${ }^{8}$.

Nie ma tu żadnej wzmianki o sumariuszach, a sprawozdawczość poboru podatku została oparta na kwitacjach, które poborcy wydawali płatnikom, nie zaś - co zostało wyraźnie podkreślone - na rejestrach poborowych i zawartych w nich informacjach. W połączeniu z przewidzianym przez uniwersał mechanizmem rejestrowania kwitacji przez proboszczów i późniejszego porównywania sum pobranych podatków zestawianych przez poborców z zestawieniami sum z kwitacji rejestrowanych przez proboszczów - otrzymujemy bardzo przejrzysty system weryfikacji uczciwości osób wybierających podatek. Fakt, że rozwiązanie to miało służyć właśnie weryfikacji uczciwości poborców, wynika jasno z treści samego uniwersału: „quandoquidem haec res non propter aliud fieri debet, quam ad cognoscendam verius exactorem fidelita-

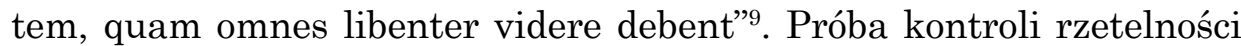
poborców w oparciu o sporządzane przez nich rejestry byłaby operacja niemajacca sensu. Nieuczciwy poborca - gdyby miał zamiar zawłaszczyć pieniądze z podatków - po prostu, otrzymawszy wpłatę, nie wprowadziłby jej do rejestru poborowego. W tej sytuacji oparcie sprawozdawczości na kwitacjach wydawanych płatnikom podatku i ich niezależnej rejestracji przez struktury kościelne wydaje się działaniem głęboko przemyślanym.

Oczywiście pojawia się w tym miejscu pytanie, czy w praktyce udało się twórcom tego rozwiązania wprowadzić je w życie. Być może odpowiedź znajduje się w źródłach kościelnych, choć brak jakichkolwiek nawiązań do tego rozwiązania $\mathrm{w}$ uniwersałach poborowych $\mathrm{z}$ kolejnych sejmów zdaje się sugerować, iż zrezygnowano z niego. W dalszej

8 Tamże, s. 25.

9 Tamże, s. 26. 
części tegoż uniwersału poborowego z 1527 r. spotykamy wreszcie po raz pierwszy sumariusze poborowe:

Iidem exactores facient rationem distincte, demonstrando sigillatim, quantum ex contributione laneorum, quantum ex civili exactionem, quae schoss dicitur, quantum ex czopowe solvent, quantum ex nudis censibus et quantum ex nobilibus pauperibus, qui colonos non habent, perceperint et distribuerint, ut sciri possit, quae summa pecuniarum ex unaquaque contributionum praedictarum colligatur ${ }^{10}$.

Treść uchwały sugeruje, że nałożony na poborców w 1527 r. obowiązek sporządzania sumariuszy nie miał związku ze sprawozdawczością sejmowa. Jego celem było uzyskanie przez centralna administrację skarbową wiedzy o strukturze dochodów państwowych z wszystkich podatków nadzwyczajnych.

Poza wymienionymi powyżej rozwiązaniami regulującymi sferę kontroli i sprawozdawczości podatkowej, uniwersał poborowy z r. 1527 wprowadził także rekognicje podatkowe jako obowiazkowy dokument, którego sporządzenia wymagano od części płatników podatków. We fragmencie uniwersału regulujacym kwestię opłacania podatku od czynszów zostało wprost użyte określenie „rekognicja”, utożsamione tam z pojęciem „kwitacji”:

[...] ut omnes, qui census nudos et similiter exactionem civilem, quae schoss dicitur, et contribucionem czopowe solvent, quietantias seu recognitiones suas apud exactores relinquant, quibus declarent, quantum ex eisdem contributionibus ad manus exactorum dederint et persolverint, quo exactores ipsi possent se ab omni suspicione vendicare ${ }^{11}$.

Tak więc zostały one pomyślane jako element, który miał uzupełniać istniejący już system kwitacji wystawianych przez poborców płatnikom. W pewnym sensie było to rozszerzenie o jeden poziom w dół wypracowanej wcześniej praktyki wzajemnego kwitowania się przez poborców i szafarzy z wypłacanych lub otrzymywanych kwot, gdzie jedna strona potwierdzała wypłatę, a druga przyjęcie określonej kwoty. Rekognicja pełniłaby tutaj rolę deklaracji wpłaty, a kwitacja była potwierdzeniem jej otrzymania.

Oczywiście obowiązek operowania pisemnymi rekognicjami oznaczał kłopot dla niepiśmiennych płatników. W przypadku poboru łanowego, gdzie nie przewidywano sporządzania rekognicji przez płatników, ale

10 Tamże.

${ }^{11}$ Tamże. 
jedynie wystawianie kwitacji przez poborcę, możemy założyć, iż problem ten nie istniał. W odniesieniu jednak do pozostałych podatków, a zwłaszcza czopowego uiszczanego przez wiejskich karczmarzy, którzy niekoniecznie musieli być piśmienni, sprostanie wymogom uniwersału mogło sprawić niejaką trudność. Twórcy uchwały przewidzieli potencjalne kłopoty z tym związane i nałożyli na proboszczów obowiązek sporządzania dla niepiśmiennych płatników papierowych rekognicji:

Tabernatores vero villarum, qui scribere nesciunt, priusquam portabunt pecuniam exactionis czopowe ad exactores, praesentare se debebunt plebanis suis et illis declarare, quantum summam pecuniae contribucionis czopowe sint ad Ipsos exactore perlaturi, quam summam plebani in regestris suis annotabunt et recognitiones suas dabunt ad exactores, ut sciant, quantum ab ipsis tabernatoribus parochiae suae sint percepturi ${ }^{12}$.

Uniwersał poborowy sejmu walnego krakowskiego z 1527 r., jeśli zestawić go z wcześniejszymi i późniejszymi uchwałami podatkowymi podejmowanymi na sejmach, wydaje się pierwszym krokiem $\mathrm{w}$ trwajaccym kilka lat procesie tworzenia zbioru zasad regulujacych na nowo system poboru podatków oraz mechanizmy kontroli. Kontynuacją tych działań było wprowadzenie w $1529 \mathrm{r}$. przy poborze ziemskim praktyki zaprzysięgania poborów przez dwóch mieszkańców z każdej wsi ${ }^{13}$ oraz nałożenie na poborców obowiązków sporządzania retent, czyli wykazów osób zalegających z opłaceniem podatków, przy czym wykaz taki miał być opatrzony konkretną data jego sporządzenia ${ }^{14}$. Ostatnim elementem budowy systemu było wprowadzenie przy opłacaniu poboru łanowego w $1532 \mathrm{r}$. papierowych rekognicji sporządzanych przez właścicieli wsi ${ }^{15}$. W efekcie stworzony został cały system obiegu dokumentacji, na

12 Tamże.

${ }^{13}$ Tamże, s. 55: „ex qualibet villa duo viri, qui magis honesti et probatae vitae esse consebuntur, contributionem ex omnibus laneis possessionatis villae suae collectam ad exactorem publicum perferant et coram eo corporale iuramentum praestent ad signum seu imaginum crucifixi, quod iste ex omnibus suae villae laneis possessionatis, ita ut domino suo censum et bellicam contributionem, quae woyenne dicitur, solvunt, eam ipsam contributionem publicam exegerint et integre exactori reddiderint".

${ }_{14}$ Tamże, s. 56: „volumus et mandamus, ut exactor noster nomina eorum, qui contributiones ipsas ad ratas temporus supradictas solvere neglexerint, in scedula diligenter conscribat, in qua annotet diem, qua illam scripserit et ad capitaneum perferendam dederit, et illam vobis sigillo suo obsignatam et manu sua propria vel sui notarii subscriptam mittere teneatur".

15 Tamże, s. 106: „Quia vero multi querentur, quod contribuciones praedicte, quae pro necessitate reipublice regni laudantur et instituuntur, non integre ab exactoribus comportantur, ideo nos providere volentes, ne id, quod ab omnibus pro communi bono 
początku którego były papierowe rekognicje spisywane przez płatników podatków ${ }^{16}$. Poborcy ze swej strony wystawiali płatnikom kwitacje potwierdzające, ile podatku i z jakiego tytułu wpłacono. Następnie w oparciu o kwitacje poborcy mieli rozliczać się przed sejmikami i sejmem z wysokości wpływów podatkowych i sposobu ich wydatkowania, a w oparciu o rejestry poborowe sporządzać sumariusze na potrzeby podskarbiego koronnego.

Już jednak w drugiej z tego ciagu uchwał poborowych, najprawdopodobniej w sposób niezamierzony, system ten uległ dość poważnej zmianie. Przy okazji komponowania (ewidentnie korzystając z tekstu uniwersału poborowego z sejmu walnego krakowskiego z 1527 r. jako formularza) treści uniwersału poborowego r. 1528 uchwalonego na sejmie walnym piotrkowskim obradującym w latach 1527-1528, dokonano niefortunnego skrótu wzorcowego tekstu. W efekcie tej operacji znikną fragment, gdzie umieszczony był nakaz posługiwania się przy rozliczaniu podatków przez poborców kwitacjami, a nie rejestrami.

Idem exactor in conventu particulari, qui praecedet generalem regni conventum futurum faciet facereque tenebitur rationem de pecuniis contributionem a se percepturum et expositarum coram palatino, castellanis, dignitariis et officialibus palatinatus sui ac etiam nobilitate, facietque eandem rationem distincte, demonstrando sigillatim, quantum ex contributione laneorum, quantum ex civili exactione, quae schoss dicitur, quantum ex czopowe at quantum ex nobilibus pauperibus, qui colonos non habent, perceperit et distribuerit, ut sciri possit in futuro regni conventu, ad quem ratio et calculus omnium exactorum per palatinos terrarum aut alique ex castellanis referri et comportari debet, quae summa pecuniarum ex unaquaque contributionum praedictarum colligatur ${ }^{17}$.

et necessitate contribuitur, subductur alio in fraudem ipsius reipublice regni, decernimus et ordinamus, ut coloni, qi ad solvendas ipsas contributiones publicas obligantur, quisque ad dominum suum seu possessorem villae, quam incolit, dominus vero seu possessor villae integre et fideliter eam ipsam contributionem publicam deportare teneatur dabitque dominus seu possessor villae exactori contributionem capienti recognitionem litterariam obsignatam et subscriptam, quo evidentius appareat, quantum ex aliqua villa vel bonis ratione dictae contributionis sit solutum, quod ipsum et nobiles pauperes quisque pro se facient".

${ }^{16} \mathrm{~J}$. Senkowski (Materiały źródłowe do genezy skarbu publicznego $w$ Polsce $w$ Archiwum Głównym Akt Dawnych w Warszawie, „Archeion” 23, 1954, s. 42) słusznie zauważył, że rekognicje to dowód na wprowadzenie kontroli w systemie poboru podatku, mający uniemożliwiać zaniżanie przez poborców podstawy poboru podatku i zabieranie pieniędzy dla siebie.

${ }^{17}$ Volumina Constitutionum, t. 1, cz. 2, s. 38. 
W efekcie uchwała poborowa z 1528 r. otwierała możliwość wykorzystywania $\mathrm{w}$ sprawozdawczości sejmowej sumariuszy poborowych. W uchwale sporządzonej po kolejnym sejmie walnym w 1529 r. opuszczenie to skorygowano, zapisując wyraźnie, iż rozliczenie poboru podatków następuje w oparciu o kwitacje, a obok nich poborca ma przedstawić zestawienia $\mathrm{z}$ informacja, ile jakich podatków wybrano:

[...] facientque eandem rationem distincte, demonstrando et docendo per quietantias singillatim, quantum ex contributionibus laneorum, quantum ex civili exactione, quae schoss dicitur, quantum ex czopowe, quantum ex tabernis, quantem ex molendinis, et quantum ex nobilibus pauperibus, advocati seu scultetis, qui colonos non habent, perceperint et distribuerint, ut sciri possit in futuro regni conventu, ad quem ratio et calculus omnium exactorum per palatinos terrarum aut aliquem ex castellanis referri et comportari debet, quae summa pecuniarum ex unaquaque contributionem predictarum colligatur ${ }^{18}$.

Ale już po kolejnym sejmie walnym piotrkowskim, obradującym w latach 1530-1531, posłużono się prawdopodobnie ponownie treścią uniwersału z 1528 r., w którym sformułowanie „per quietantias” nie zostało umieszczone:

Qui quidem exactor faciet rationem distincte demonstrando singillatim quantum ex contributione laneorum, quantum ex civili exactione, quae schoss dicitur, quantum ex czopowe at quantum ex nobilibus pauperibus, qui colonos non habent, perceperit et thesauro nostro intulerit, ut sciri possit quae summa pecuniarum ex unaquaque contributionum praedictarum colligatur ${ }^{19}$.

Umożliwiało to poborcom rozliczanie się przed sejmikami i sejmem przy użyciu sumariuszy zamiast kwitacji. Treść uniwersału poborowego wydanego po sejmie walnym piotrkowskim 1538 r. wskazuje, że czynili to oni, posuwając się nawet do niszczenia kwitacji - zestawianie sprawozdania z realizacji poboru podatków powiązano w nim bowiem ponownie $\mathrm{z}$ kwitacjami i umieszczono zakaz ich rozpraszania, niszczenia czy też zatrzymywania sobie przez poborców:

Qui quidem exactor in conventu particulari palatinatus sive terrae suae proximae a nobis indicendo faciet coram nobilitate sive ab eis deputatis et deinde in conventu nostri generali proximo coram nobis et consiliariis

\footnotetext{
${ }_{18}$ Tamże, s. 58.

${ }^{19}$ Tamże, s. 88.
} 
nostris plenam rationem de omnibus contributionibus palatinatus sivae terrae, in qua fuit exactor, specifice et singillatim demonstrando quantum videlicet de singulis exactionibus suprascriptis proveniat, a qualibet seorsum faciet et referet, ut sciri possit, quae summa pecuniarum ex unaquaque contributionum praedictarum colligatur [...] Quietationes vero antiquas non debent exactores discepere sive lacerare vel ipsas ad se recipere, sed eas rursus his, qui eas attulerunt, restituere pro officio vestro et gratia nostra aliter non facturi ${ }^{20}$.

W kolejnych uchwałach poborowych regulacja dotyczaca sposobu zdawania sprawozdań z wykonania uchwał podatkowych już się nie pojawiała, natomiast regularnie powtarzany był (z pewnymi modyfikacjami) fragment dotyczący obowiązku przechowywania kwitacji, opatrywany dodatkowo szczegółowymi regulacjami zasad ich sporządzania ${ }^{21}$. Nakazano między innymi umieszczanie na kwitacjach wydawanych płatnikom daty otrzymania wpłat, która to regulacja po raz pierwszy pojawiła się $\mathrm{w}$ uniwersale poborowym sejmu walnego krakowskiego z lat 1538-153922. Ta sama data dokonania wpłaty miała być zapisana także w rejestrze poborowym. Domyślać się tu można, że regulacja miała na celu wyeliminowanie zarówno możliwości posługiwania się kwitacjami z lat poprzednich przez płatników, jak i sytuacji, gdy mimo opłacenia - co prawda po terminie - podatku płatnik był zmuszany do zapłacenia podatku po raz drugi, gdyż figurował w wykazie retent.

Dalsze zmiany mechanizmu poboru podatków nastapiły w latach 50. i 60. Najpierw, po sejmie piotrkowskim 1552 r., pojawił się w uniwersale odgórny nakaz sporządzania spisów podatkowych w układzie parafialnym ${ }^{23}$. Od sejmu lat 1562-1563 wprowadzono nakaz podpisywania rekognicji podatkowych przez właściciela bądź zarządcę majątku ${ }^{24}$. W latach 60 . powracaja też do treści uniwersałów zapisy mówiące o obowiązku przedstawienia na sejmikach i sejmach sprawozdań z poboru podatków. Najciekawszy pod tym względem jest chyba uniwersał z r. 1565, kiedy to, zapewne by podnieść poziom wpływów podatkowych, pojawił się zapis przewidujący porównanie na sejmie wpływów $\mathrm{z}$ aktualnie uchwalonego poboru z wpływami z dwóch poprzednich lat podatkowych: „Przy ktorej liczbie teraźnieiszych poborzec, poborce lat dwu przeszłych być i liczbę swoię weryfikować maia,

\footnotetext{
20 Tamże, s. 184.

${ }^{21}$ Tamże, s. 227, 240, 270.

22 Tamże, s. 207.

${ }^{23}$ Volumina Constitutionum, t. 2: 1550-1609, cz. 1: 1550-1585, oprac. S. Grodziski, I. Dwornicka, W. Uruszczak, Warszawa 2005, s. 37.

${ }^{24}$ Tamże, s. 116-117.
} 
aby się i tych przeszłych poborzec wiara, dzielność i chuć przeciw Nam i Rzeczypospolitej tym iaśniej pokazać mogła" ${ }^{25}$.

Wracając do kwestii sumariuszy poborowych i ich pierwotnego przeznaczenia, wypada stwierdzić, że w chwili wprowadzenia w $1527 \mathrm{r}$. nie stanowiły one elementu sprawozdawczości sejmowej ani też składnika systemu rozliczania się poborców z podskarbim. Do tego służyć miały w zamierzeniu kwitacje, które nie były w systemie podatkowym niczym nowym, gdyż wystawiano je już w trakcie wybierania podatków jeszcze w XV w. Weryfikacja wpływów podatkowych w oparciu o sumariusze nie dawała bowiem możliwości wychwycenia ewentualnych oszustw popełnianych przez poborców. W sposób niezamierzony przez twórców systemu, ale - jak się wydaje - ostatecznie zaakceptowany przez nich, wytworzyła się praktyka opierania sprawozdawczości sejmikowej i sejmowej na sumariuszach. Prawdopodobnie wystarczajacym zabezpieczeniem przed potencjalna nieuczciwością poborców okazał się obowiązek przechowywania kwitów, a z czasem także rekognicji. Nawet w Egzorbitacjach okołopoborowych ich autor wśród praktyk stosowanych przez nieuczciwych poborców nie umieścił pobierania podatku od płatników bez wciagania informacji o tym do rejestru poborowego. Jego zdaniem tego rodzaju praktyka możliwa była jedynie w odniesieniu do dóbr własnych poborcy ${ }^{26}$. Oszustwo polegające na nieodnotowywaniu $\mathrm{w}$ rejestrze pobrania podatku wymagałoby bowiem rezygnacji z wystawienia pokwitowania wpłaty.

Skoro więc $\mathrm{w}$ zamierzeniach twórców reformy systemu poboru podatków z lat 20. i 30. XVI w. sumariusze nie miały służyć sprawozdawczości sejmowej, rodzi to pytanie o cel ich stworzenia. Ponieważ brak w tym zakresie jakichkolwiek regulacji ustawodawczych zarówno w uniwersałach poborowych, jak i w ordynacjach skarbowych, skazani jesteśmy na posłużenie się dedukcja. W przywołanej na początku artykułu opinii Pawińskiego sumariusze miały być narzędziem służącym do podsumowania budżetu minionego roku. Zapewne podstawą tego twierdzenia była treść uchwał poborowych, w których pojawia się sformułowanie, że poborcy poprzez sumariusze mają wykazać, ile z jakich podatków przyszło pieniędzy i nawet precyzyjnie wyliczyć, ile - z łanów kmiecych, szlacheckich, ile - z karczem, młynów itp. Jednak do analizy wykonania budżetu minionego roku i rozliczenia się podskarbiego $\mathrm{z}$ wykonania uchwał podatkowych przed sejmem znaczenie miały tylko

${ }^{25}$ Tamże, s. 189-190.

${ }^{26}$ K. Górska, Przyczynek do krytyki rejestrów poborowych z XVI wieku, „Studia Źródłoznawcze” 1, 1957, s. 188-189. 
globalne kwoty wpływów podatkowych, a wiedza na temat liczby opodatkowanych w danym roku łanów nie odgrywała żadnej roli. W trakcie obrad sejmowych należało bowiem przedstawić globalną kwotę wpływów (bez szczegółowej informacji o ich strukturze), a rzeczą najważniejszą była informacja o sposobie ich rozdysponowania. Podstawa do odmówienia wystawienia przez sejm lub jego deputację kwitacji dla podskarbiego było bowiem niezgodne z przeznaczeniem wydatkowanie ściagniętych podatków, a nie ich wewnętrzna struktura ${ }^{27}$. Na dodatek w obrębie poszczególnych lat kalendarzowych budżet tworzyły często wpływy nie z jednej uchwały podatkowej, ale często z dwóch, gdyż proces pełnego zrealizowania poboru (łacznie z retentami) trwał zwykle 2-3 lata. W tej sytuacji wiedza o liczbie opodatkowanych łanów czy też karczem nie była do niczego przydatna. By właściwie umiejscowić sumariusze $\mathrm{w}$ systemie podatkowym szesnastowiecznego Królestwa Polskiego i określić najbardziej prawdopodobne pierwotne ich przeznaczenie, należy więc sięgnąc do nich samych i w ich treści poszukać wskazówek.

Przede wszystkim uwage zwraca fakt, iż obok pojedynczych, rozproszonych między różnymi rejestrami podatkowymi sumariuszy dla poszczególnych ziem lub powiatów dysponujemy dla kilku lat zachowanymi dużymi ich zbiorami obejmującymi - z mniejszymi czy większymi lukami - całe terytorium ówczesnego Królestwa Polskiego. Nie stanowią one jednolitego zespołu archiwalnego, ale znajduja się w kilku księgach pozostajacych w zbiorach AGAD w oddziale pierwszym i drugim Archiwum Skarbu Koronnego (dalej: ASK). Łacznie mamy zachowanych dziewięć zbiorczych sumariuszy odpowiadających uchwałom podatkowym z lat: $1533^{28}, 1535^{29}, 1543^{30}, 1552^{31}, 1553^{32}, 1563^{33}, 1564^{34}$, $1565^{35}$ i $1569^{36}$. Listę tę wypadałoby uzupełnić o sumariusz poboru

${ }^{27}$ A. Pawiński, dz. cyt., t. 8, s. 301. Przypadki odmowy wystawienia kwitacji sejmowej dla podskarbiego, zawsze związane z zakwestionowaniem sposobu wydatkowania części ściagniętych podatków, omawia dla późniejszego okresu A. Filipczak-Kocur, Skarbowość Rzeczypospolitej 1587-1648. Projekty - ustawy - realizacja, Warszawa 2006.

${ }^{28}$ AGAD, ASK, o. I, ks. 35, k. 202-255.

${ }^{29}$ AGAD, ASK, o. I, ks. 2, k. 145-166.

${ }^{30}$ AGAD, ASK, o. I, ks. 61, k. 766-805.

${ }^{31}$ AGAD, ASK, o. II, ks. 19, s. 7-143.

${ }^{32}$ AGAD, ASK, o. II, ks. 19, s. 3a-101a.

${ }^{33}$ AGAD, ASK, o. I, ks. 94, k. 1-72, oraz AGAD, ASK, o. II, ks. 24, k. 4-67.

${ }^{34}$ AGAD, ASK, o. II, ks. 24, k. 75-188.

${ }^{35}$ AGAD, ASK, o. II, ks. 24, k. 197-312.

${ }^{36}$ AGAD, ASK, o. I, ks. 112, k. 1-182. 
z 1578 r., do którego jednak nie zdołałem jeszcze dotrzeć. Prawdopodobnie przechowywany jest on aktualnie w Centralnym Państwowym Archiwum Historycznym Ukrainy w Kijowie, w długo uznawanej za zaginiona księdze oddziału LIV Archiwum Skarbu Koronnego oznaczonej sygnatura $14 \mathrm{~B}^{37}$. W polskiej historiografii zostały one wykorzystane badawczo na szerszą skale przez wspomnianych już Adolfa Pawińskiego oraz Irenę Gieysztorową. Pawiński wykorzystał dane zawarte w sumariuszu poboru 1569 r., tworząc zestawienia zmiany liczby łanów kmiecych w 2. połowie XVI w. w poszczególnych województwach Królestwa Polskiego ${ }^{38}$, oraz dane z sumariusza dla 1578 r., tworzac zestawienia wpływów z łanowego ziemskiego, miejskiego i szosu dla 1578 r. $^{39}$, a także porównawcze zestawienie wpływów z czopowego dla lat 1578$-1583^{40}$. Brak natomiast $\mathrm{w}$ jego pracy śladów korzystania z pozostałych zachowanych sumariuszy zbiorczych. Z kolei Gieysztorowa w trakcie pracy nad opublikowanym w 1958 r. artykułem poświęconym przemianom gospodarczym na wsi mazowieckiej w XVI w. ${ }^{41}$ dotarła do wszystkich przechowywanych w AGAD sumariuszy zbiorczych, przy czym badawczo wykorzystała dwa z nich, z lat 1533 i 1564, umieszczając w przypisie informację o lokalizacji wszystkich zachowanych ${ }^{42}$. Obydwoje jednak nie do końca precyzyjnie opisali zawartość tych źródeł. Z ich publikacji można bowiem wywnioskować, że wykorzystywane przez nich sumariusze zbiorcze to zestawienia wpływów jedynie z poboru ziemskiego. Tymczasem są to zbiorcze zestawienia wpływów ze wszystkich podatków nadzwyczajnych (poboru ziemskiego, szosu, czopowego, pogłównego żydowskiego i ewentualnie innych, takich jak np. podatek łasztowy czy też nadzwyczajne 25-procentowe cło), uchwalonych dla danych lat, z uwzględnieniem zwykle także retent oraz z dołączoną ogólną informacją na temat ich wydatkowania. Różnią się one od siebie przede wszystkim zasięgiem terytorialnym zachowanych danych. Najskromniejszy zasięg ma sumariusz 1535 r., obejmujący jedynie część Małopolski, Mazowsze i Kujawy. Najszerszy zasięg terytorialny maja sumariusze dla 1563 i 1569 r. Sumariusz 1563 r. zachował się w dwóch częściach, z których jedna znajduje się w oddziale I ASK i zawiera głównie sumariusze poszczególnych powiatów i ziem bez

${ }^{37}$ Informację o aktualnym miejscu przechowywania księgi 14B podaje A. Filipczak-Kocur, dz. cyt., s. 34, przyp. 64. Jej aktualna sygnatura to: f. 1, op. 1, nr 2, k. 162.

${ }^{38}$ A. Pawiński, dz. cyt., t. 8, s. 151-152.

39 Tamże, s. 148-150.

40 Tamże, s. 171.

${ }^{41}$ I. Gieysztorowa, dz. cyt., s. 236-249.

${ }^{42}$ Tamże, s. 237, przyp. 4. 
retent, podczas gdy część druga (znajdująca się w oddziale II ASK) zawiera - obok niektórych pierwotnych sumariuszy - przede wszystkim wykazy wpływów z retent. W przypadku sumariusza dla 1569 r. zakres uwzględnienia retent $\mathrm{w}$ porównaniu do r. 1563 jest dużo mniejszy, ale za to jako jedyny spośród zachowanych sumariuszy zawiera on dane dla Prus Królewskich i Warmii (bez Gdańska) i wykazuje generalnie najmniejsze braki terytorialne. Nie ma w nim bowiem jedynie danych dla województwa lubelskiego (dla którego sumariusz zachował się odrębnie ${ }^{43}$ ) oraz części danych dla powiatu żydaczowskiego (brak jednej karty).

Wszystkie sumariusze przechowywane w AGAD, począwszy od najstarszego z r. 1533, były spisywane wedle jednolitego schematu. Ułożone sa województwami, przy czym zwykle pierwsze w wykazie jest województwo krakowskie. W obrębie poszczególnych województw dane podatkowe ułożone sa według powiatów lub ziem. Informacje o wpływach podatkowych $\mathrm{z}$ danej jednostki administracyjnej zaczynają się zawsze od danych dla poboru ziemskiego. Do wyjątków należy sytuacja, gdy mamy do czynienia jedynie z podaniem kwoty zbiorczej wpływów z danego okręgu podatkowego. Zwykle w dokumencie widnieje szczegółowe zestawienie informacji o liczbie jednostek poszczególnych kategorii podatkowych wyodrębnionych w uniwersale, stawce podatku i kwocie wpływów. Po poborze ziemskim zwykle umieszczany był szos, następnie czopowe i pogłówne żydowskie. W najstarszych sumariuszach dla tych trzech podatków podawane były zwykle tylko zbiorcze sumy wpływów w obrębie powiatu lub ziemi. W sumariuszach z lat 50. XVI w. także one staja się szczegółowe i zawieraja np. wykazy miast z podanymi kwotami zapłaconego szosu i czopowego, a czasem nawet pojawia się informacja o liczbie war i stawce podatkowej za warę.

Do lat 50. sumariusze były sporządzane zwykle przez kilka osób. Począwszy od lat 60. są już w całości sporządzane tylko jedną ręka. Od początku mamy do czynienia z wypracowanym schematem nagłówków sumariuszy cząstkowych poszczególnych powiatów, ziem czy województw (patrz il. 2). Pojawia się tam zawsze informacja o tym, kto (zwykle podskarbi koronny) od kogo (konkretny poborca podatkowy) odebrał informację o dochodach i ich strukturze oraz gdzie i kiedy miało to miejsce. Spotkania te, sądząc po datach pojawiających się w nagłówkach, w większości odbywały się w czasie trwania obrad sejmu walnego, ale terminy spotkań były silnie rozproszone. Większość sumariuszy

${ }^{43}$ AGAD, ASK, o. I, ks. 33, k. 689. 
powiatów i ziem poboru 1563 r. jest opatrzona datami przypadającymi na czas obrad sejmu piotrkowskiego 1565 r. (od 18 I do 14 IV 1565 r.). Jeden nosi datę 9 II, trzy datę 19 II, dwa datę 28 II, jeden datę 13 III, jeden datę 27 III, jeden datę $10 \mathrm{IV}$, dwa datę 14 IV. Jednocześnie jednak cały szereg spotkań z poborcami odbył się w Piotrkowie zarówno przed rozpoczęciem obrad sejmowych (po jednym spotkaniu w dniach: 9 I, 11 I i 16 I), jak i po ich zakończeniu (po jednym spotkaniu w dniach 16 IV i 18 IV). Na jednym z sumariuszy czastkowych widnieje nawet data 22 III 1566 r., a jako miejsce podany jest Kraków, tak więc spotkanie to nie miało związku z odbywaniem się któregokolwiek z sejmów walnych.

W przypadku sumariusza za $1564 \mathrm{r}$. mamy do czynienia z ciagiem spotkań podskarbiego z poborcami w okresie dwóch sejmów walnych: lubelskiego, odbywającego się od $8 \mathrm{~V}$ do 21 VIII 1566 r., i piotrkowskiego, obradującego od 7 IV do 20 VI 1567 r. Ale dwa spotkania wyłamują się z tego schematu. Spotkanie z poborca ziemi czerwińskiej miało miejsce w Warszawie 29 X 1566 r., a z poborca ziemi rawskiej 21 VI 1567 r. w Warszawie. Można więc sądzić, że spotkania te nie miały jakiegokolwiek związku ze sprawozdawczościa sejmowa. Rozliczenie bowiem wysokości wpływów podatkowych i sposobu ich wydatkowania winno nastapić, wedle regulacji przyjętych na sejmie 1563 r., szóstego dnia od momentu otwarcia obrad sejmowych ${ }^{44}$. Nie wyklucza to oczywiście wykorzystywania danych zawartych w sumariuszach na potrzeby tejże sprawozdawczości, ale rodzi się pytanie o cel osobistych spotkań podskarbiego z poborcami. Odpowiedź na nie znajduje się $\mathrm{w}$ treści samych sumariuszy. Po pierwsze, mamy tu do czynienia nie $\mathrm{z}$ oryginalnymi sumariuszami sporządzanymi przez pisarzy poborowych na zlecenie poszczególnych poborców, ale z (jak już wcześniej wspomniano) odpisami oryginalnych sumariuszy. Zestawieniu wpływów zawsze towarzyszą zestawienia wypłat pieniędzy dokonanych przez poborców na ręce depozytariuszy lub innych osób. Część sumariuszy cząstkowych była uzupełniana po upływie pewnego czasu o dane dotyczące wpływów z retenty oraz informacje o dalszych wypłatach zebranych pieniędzy i opatrywana informacją o czasie i miejscu kolejnego spotkania z poborca. Najistotniejszym elementem wydają się jednak umieszczone na marginesach poszczególnych sumariuszy adnotacje oraz umieszczone na końcu komentarze. Oto końcowy fragment sumariusza województwa kaliskiego z 1569 r.:

${ }^{44}$ A. Filipczak-Kocur, dz. cyt., s. 24-25. 


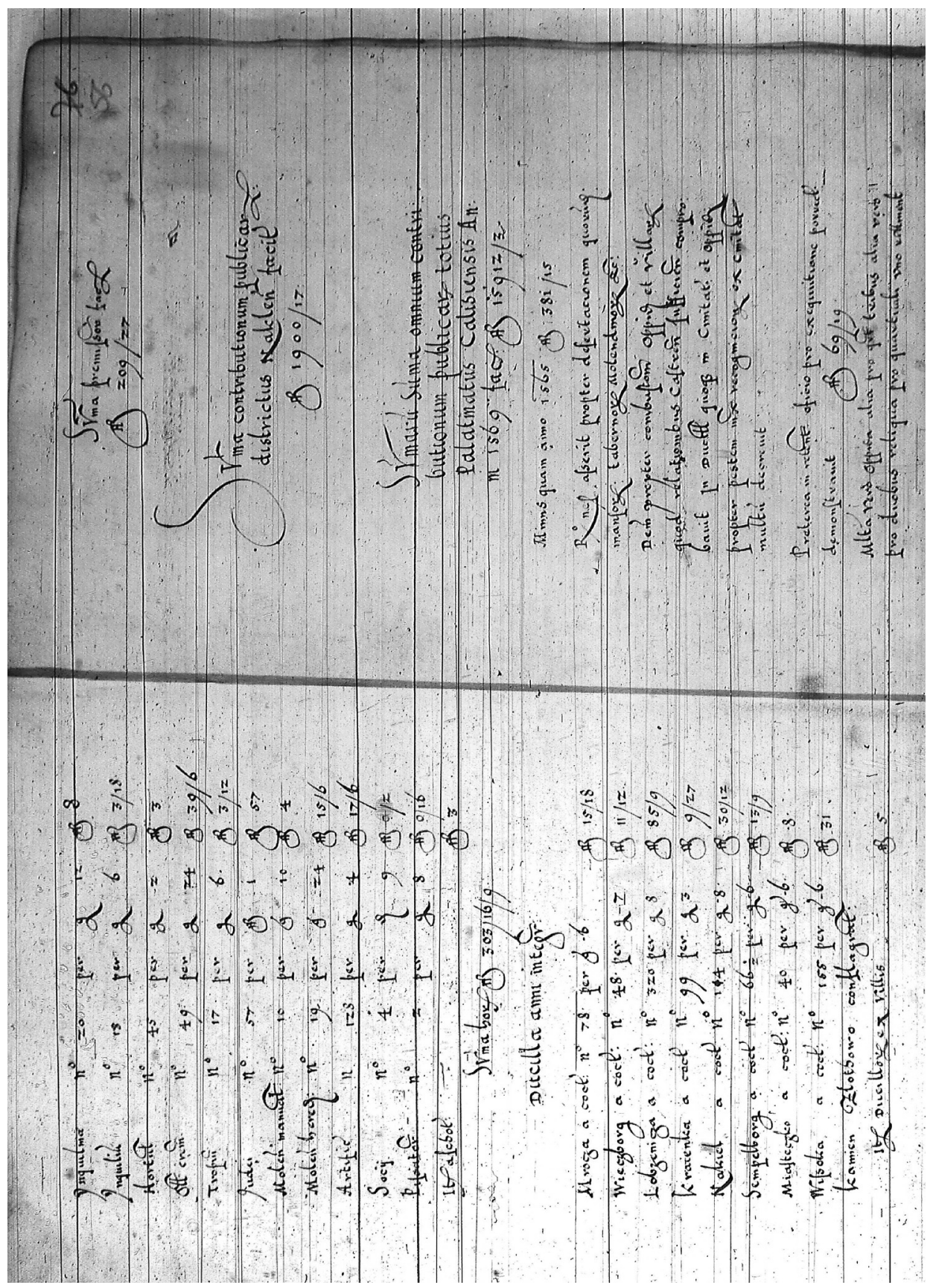


Minus quam anno 1565 fl 381/15

Rationes asserit propter desertacionem quorundem mansorum, tabernorum, molendinorum Redemit propter combustonum oppidis et villarum quod relationibus castrensis sufficientem comprobauit. In ducillam quoque in Ciuitatem et oppidum propter pestem iuxta recognicionum ex ciuitatem multum decreuit.

Preterea in retentam oficio pro exequtione porrecct demonstrauit fl $69 / 19$.

Multa vero oppida alia pro quartali tribus alia vero pro duobus reliqua pro quartale uno rettinent ${ }^{45}$.

Z fragmentu tego wynika, że spotkania poborców z podskarbim rzeczywiście się odbywały, a w ich trakcie poborcy byli indagowani o przyczyny zmian w strukturze wpływów skarbowych z ich okręgów. Często adnotacje o różnicach wpływów podatkowych pojawiają się nie na końcu sumariuszy, ale na marginesach obok poszczególnych pozycji podatkowych (jak łany kmiece, młyny itp). Przykładem może tu być pierwsza strona sumariusza powiatu sieradzkiego dla 1569 r. (zob. il. 2), gdzie na marginesie umieszczone zostały informacje o poziomie ubytków $\mathrm{w}$ podstawie opodatkowania $\mathrm{w}$ porównaniu $\mathrm{z}$ poprzednim poborem. Tego rodzaju dopiski występują także we wszystkich wcześniejszych zachowanych sumariuszach. Przy założeniu przyjętym przez Pawińskiego, że sumariusze pełniły rolę narzędzi pozwalających zamknać poszczególne lata podatkowe i ocenić wykonanie uchwały poborowej, tego rodzaju adnotacje na marginesach oraz komentarze na końcu sumariuszy nie miałyby najmniejszego sensu. Istotna wówczas byłaby jedynie informacja o ogólnej kwocie zebranych podatków i sposobie ich wydatkowania (a więc klasyczna sprawozdawczość na potrzeby deputacji sejmowej), podczas gdy wewnętrzna struktura wpływów podatkowych nie miałaby żadnego znaczenia i jej analizowanie byłoby bezprzedmiotowe. Uchwały sejmowe nie precyzowały bowiem ani czasstkowych kwot wpływów podatkowych czy też liczby płatników, których należało obciążyć podatkami, ani nie określały globalnej kwoty podatków do ściagnięcia. Z cała pewnością też do oceny wykonania uchwały poborowej niepotrzebne były informacje o skali zwolnień podatkowych w rodzaju tych umieszczonych na marginesie sumariusza województwa krakowskiego z 1535 r. Po podaniu kwot wpływów z poszczególnych kategorii podatkowych dodano tam bowiem informacje o liczbie jednostek zwolnionych z podatku, które przecież nie przyniosły żadnych wpływów do skarbu (zob. il. 3).

${ }^{45}$ AGAD, ASK, o. I, ks. 112, k. 56. 


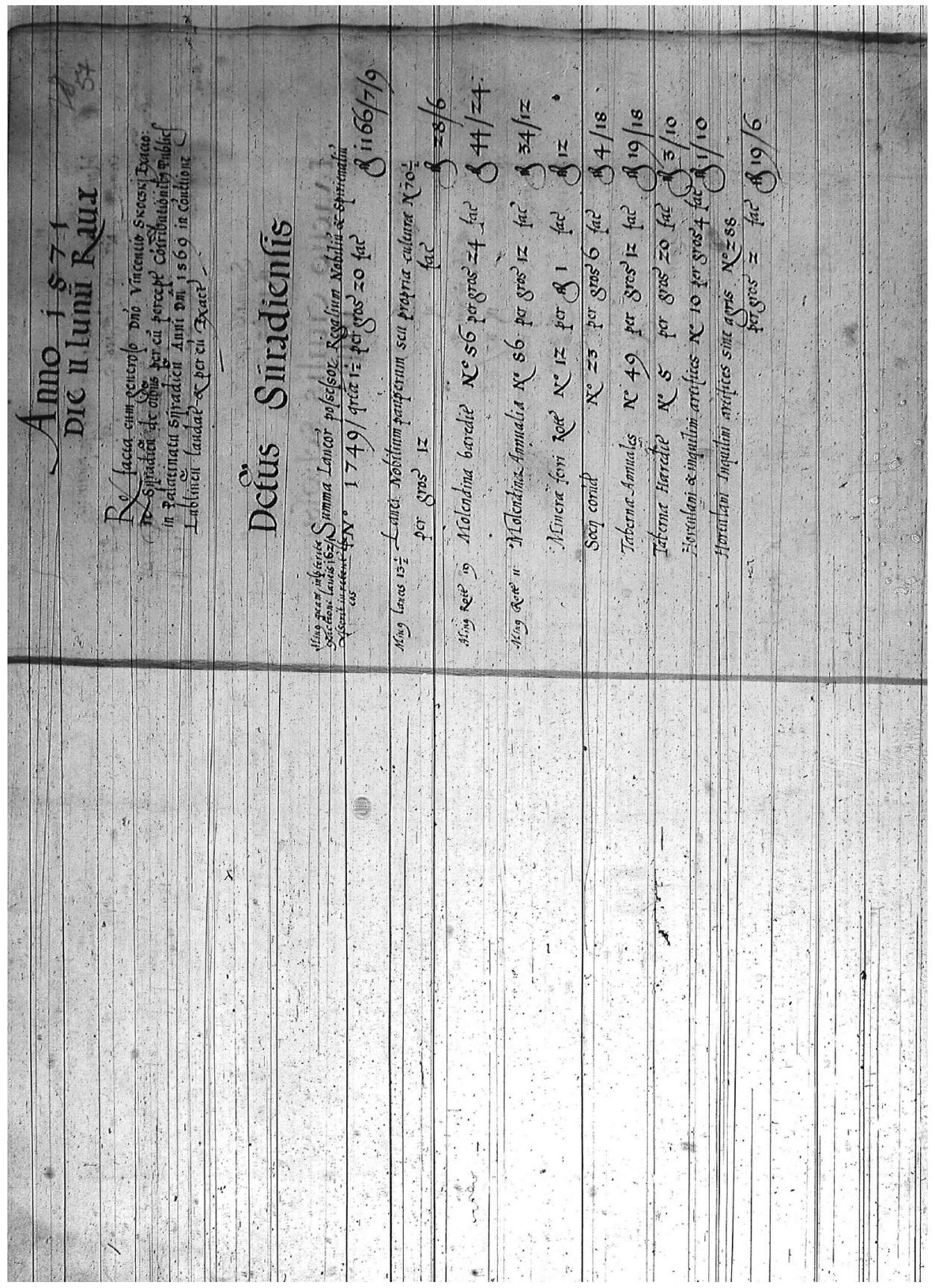




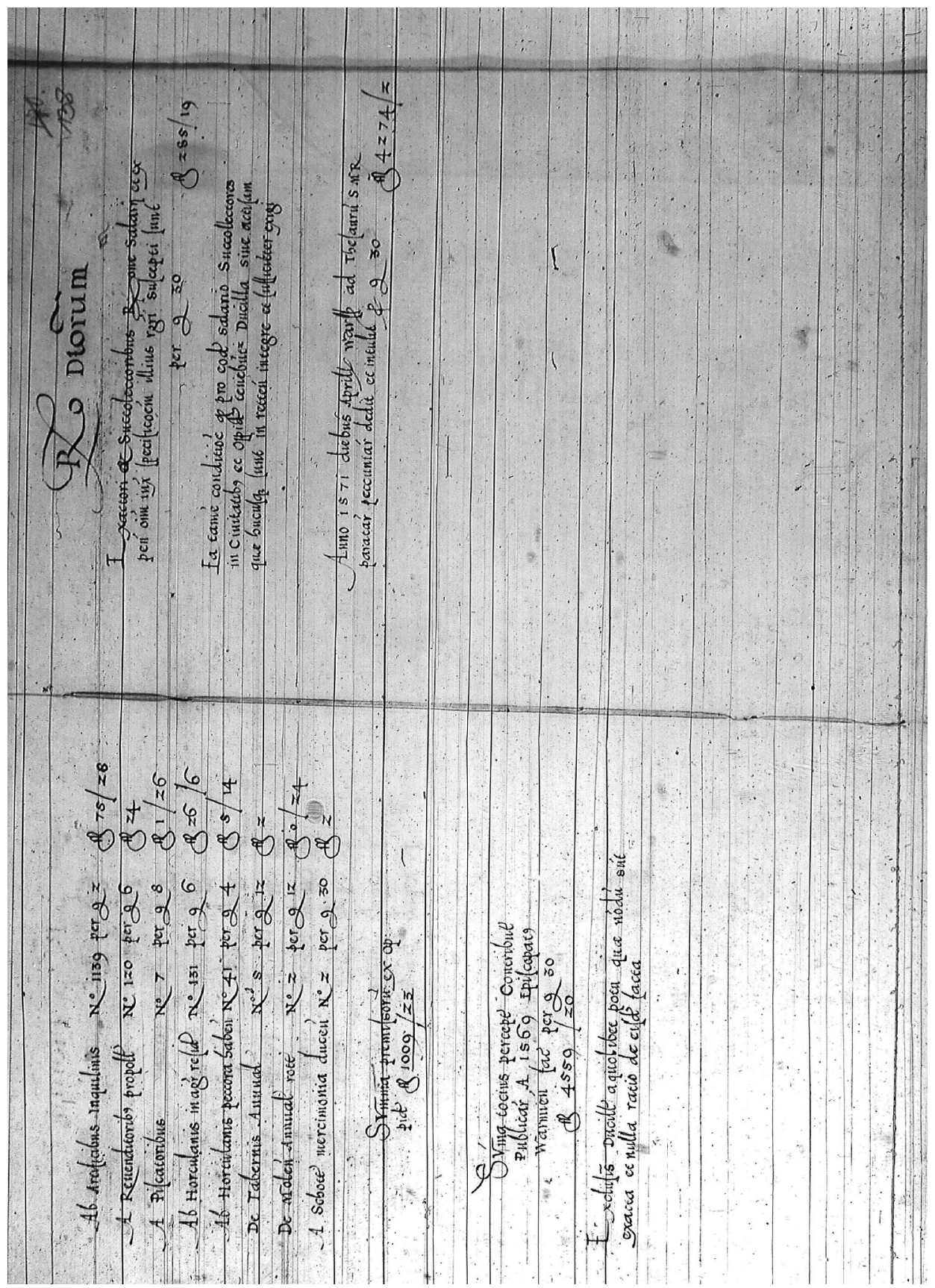


Czemu więc służyły rozbudowane sumariusze, praktyka indagowania poborców o przyczyny zmian wpływów w porównaniu z latami poprzednimi czy też śledzenie zmian w liczbie opodatkowanych jednostek w obrębie poszczególnych kategorii podatkowych? Jedynym uzasadnieniem tych praktyk wydaje się fakt aktywnego planowania budżetu na kolejne lata $\mathrm{w}$ oparciu o dochody $\mathrm{z}$ lat minionych. Tylko $\mathrm{w}$ takiej sytuacji uzasadnione staje się z jednej strony wymaganie od poborców sporządzania sumariuszy, a z drugiej wychwytywanie (poprzez porównywanie sumariuszy z różnych lat) zmian we wpływach z podatków i dociekanie ich przyczyn na drodze indagowania poborców. Wiedza o liczbie poszczególnych elementów podstawy opodatkowania (liczba łanów, kół młyńskich czy też karczem) pozwalałaby na szacowanie potencjalnych wpływów przy zakładaniu różnych stawek podatkowych. Praktyczne wykorzystywanie informacji zawartych w sumariuszach (a konkretnie wiedzy o liczbie łanów kmiecych) przy planowaniu budżetu przez ówczesne elity polityczne potwierdzają pośrednio diariusze sejmowe ${ }^{46}$.

Wprowadzenie w końcu lat 20. XVI w. obowiązku sporządzania sumariuszy przez poborców poprzedzał cały szereg działań ze strony króla Zygmunta I i jego otoczenia, zmierzających do zwiększenia dochodowości skarbu publicznego ${ }^{47}$, oraz zakończone niepowodzeniem starania o relucję pospolitego ruszenia, mającego zapewnić (w zastępstwie wojsk regularnych) bezpieczeństwo militarne południowo-wschodnim rubieżom państwa ${ }^{48}$. Równolegle do wprowadzania przedstawionych powyżej nowych rozwiązań, które miały usprawnić i uszczelnić system ściagania podatków, podejmowane były też w tym czasie działania w celu zwiększenia dochodowości domeny królewskiej poprzez zwiększenie kwot dzierżawnych, jak też skup i konsolidację majętności królewskich ${ }^{49}$. Liczba zachowanych do dzisiaj sumariuszy sugeruje intensywne ich wykorzystywanie na potrzeby „analiz budżetowych”, polegających na badaniu struktury poprzednich dochodów podatkowych i kalkulowanie ich przyszłej wysokości. Na potrzeby sprawozdawczości sejmowej wyko-

${ }^{46} \mathrm{~K}$. Boroda, Kmieć, tan czy profit? Co było podstawa poboru łanowego w XV $i$ XVI wieku?, w: Człowiek wobec miar i czasu w przeszłości, red. P. Guzowski, M. Liedke, Kraków 2007, s. 162-163.

${ }^{47}$ A. Sucheni-Grabowska, Monarchia dwu ostatnich Jagiellonów, cz. 1: Geneza ruchu egzekucyjnego, Wrocław-Warszawa-Kraków-Gdańsk 1974, s. 27-36.

${ }^{48}$ A. Wyczański, $Z$ dziejów reform skarbowo-wojskowych za Zygmunta I. Próba relucji pospolitego ruszenia, „Przegląd Historyczny” 43, 1952, z. 2, s. 287-304.

${ }^{49}$ A. Sucheni-Grabowska, Odbudowa domeny królewskiej w Polsce 1504-1548, Warszawa 2007, s. 227-229. 
rzystywane były zapewne tylko te ich części, które zawierały informacje: komu, kiedy i jaką kwotę z zebranych podatków poborca wypłacił.

Tak więc począwszy od końca lat 20 . XVI w. aż po przełom lat 60. i 70. sposobu na zwiększenie dochodów podatkowych upatrywano $\mathrm{w}$ dwóch typach działań ${ }^{50}$. Z jednej strony starano się maksymalnie rozszerzać grupę osób objętych opodatkowaniem (widoczne jest to zwłaszcza w latach 60. XVI w.), co doprowadziło do sytuacji, w której pobór ziemski stał się podatkiem $\mathrm{w}$ zasadzie powszechnym ${ }^{51}$. Wcześniej natomiast koncentrowano się przede wszystkim na wysiłkach zmierzajacych do uszczelnienia systemu wybierania podatków, by wyeliminować potencjalne nadużycia zarówno ze strony płatników, jak i poborców. Towarzyszyła temu zarazem wzmożona, zwłaszcza w latach sejmów egzekucyjnych, presja na poborców, by wkładali jak najwięcej wysiłku w zwiększenie dochodów skarbowych. Sądząc po wspomnianych adnotacjach na marginesach i zakończeniach sumariuszy, nie przynosiło to w pełni zamierzonych rezultatów. Zwyżkę dochodów dawało rozszerzanie podstawy opodatkowania o nowe kategorie ludności wiejskiej, w mniejszym zakresie o nowe elementy infrastruktury. Najlepsze efekty zapewniało jednak podnoszenie stawek podatkowych lub nakładanie nowych podatków, takich jak wybierane w latach 60 . łasztowe czy też nałożone w 1565 r. dodatkowe 25-procentowe cło na towary wywożone poza granice Królestwa Polskiego. Ale nowe podatki wymagały stworzenia systemu ich poboru i kontroli rzetelności wybierania. A to oznaczało koszta.

Zaniechanie sporządzania sumariuszy zbiorczych zbiega się w czasie ze zmianami w filozofii funkcjonowania systemu podatkowego, co stało się widoczne za panowania Stefana Batorego, a w pełni uwyraźniło się za czasów Zygmunta III Wazy. Przejawiło się to odchodzeniem od wybierania podatków w oparciu o aktualne zeznania podatkowe i praktykowaniu ściagania ich w oparciu o stare kwity jako wielokrotności stawek podatkowych. Czyniło to bezprzedmiotowym tworzenie zbiorczych sumariuszy. Bynajmniej jednak nie należy tych praktyk uznawać za dowód zapaści systemu podatkowego i upadek administracji skarbowej. W praktyce tej należałoby raczej upatrywać przejawów racjonalnego podejścia do problemu, którym okazały się z jednej strony

${ }^{50}$ Sucheni-Grabowska (Monarchia dwu ostatnich Jagiellonów, cz. 1, s. 25-27) wskazuje, że usilne dążenie do zwiększenia dochodów skarbowych zaczyna się wraz z panowaniem Zygmunta Starego. Początkiem jest tu r. 1507, w którym sejm uchwalił bicie nowej monety oraz nowe cło na woły i skóry wołowe. Ponieważ jednak dochody te okazały się niewystarczające, król zaczął starać się o zwiększenie dochodów z podatków.

${ }^{51}$ K. Boroda, dz. cyt., s. 158-161. 
zbyt niskie (w porównaniu z potrzebami) wpływy skarbowe, a z drugiej strony ich duża nieprzewidywalność. Zamiast borykać się z bezustanna tendencją spadkową wpływów podatkowych, za efektywniejsze uznano prawdopodobnie takie przetworzenie systemu poboru podatków, by był on w stanie skuteczniej zapewnić dochody niezbędne do zabezpieczenia potrzeb finansowych państwa.

Początków tego nowego podejścia do spraw podatkowych wolno upatrywać w powrocie w końcu lat 70. XVI w. do praktyki wydzierżawiania czopowego $0^{52}$. Poprzedzone to było w latach 60 . próbą zwiększenia wpływów skarbowych z tego podatku, przejawiajacca się zakazem dzierżawienia go ${ }^{53}$. Oczywiście można w tym miejscu utyskiwać na nieracjonalność takiej polityki, prowadzącej do uszczuplenia wpływów podatkowych, gdyż kwoty uzyskiwane $\mathrm{z}$ dzierżawy były zawsze mniejsze niż pozyskiwane przy wybieraniu samodzielnym. W praktyce uszczuplenie to było jednak nieznaczne, gdyż przejście do dzierżawy oznaczało redukcję (a w zasadzie likwidację) kosztów organizacji poboru podatków, które od tej chwili ponosił dzierżawca. Dzierżawa likwidowała też nieprzewidywalność wpływów podatkowych, a czopowe charakteryzowało się właśnie dużymi wahaniami przychodów rok do roku. Jednocześnie rozwiązywało to problem powolnego napływania środków do skarbu. Podatek ten wybierany był bowiem w systemie kwartalnym, co powodowało napływ pieniędzy relatywnie niedużymi kwotami przez cały rok. Tymczasem potrzeby finansowe państwa wcale nie musiały być dopasowane do tego nieregularnie płynącego strumienia środków. Z punktu widzenia potrzeb skarbowych nieistotne było, jaka technika zostanie zastosowana, by je zaspokoić: czy będzie to dzierżawa, opodatkowanie w oparciu o aktualne zeznania podatkowe, czy też pobór zryczałtowany, jak

${ }^{52}$ Volumina Constitutionum, t. 2, cz. 1, s. 441 - uniwersał poborowy sejmu walnego warszawskiego 1579-1580; s. 463 - uniwersał poborowy sejmu walnego warszawskiego 1581: „A wybieranie łasztowego od zboża, które do portu spuszczaia, także czopowego wszelakiego w miastach i miasteczkach duchownych i świeckich, poczaćc się ma od skończenia teraźniejszego czopowego, a ma trwać rok zupełny. Które arendować ku lepszemu pożytkowi pozwalamy”.

${ }^{53}$ Tamże, s. 115 - uniwersał poborowy sejmu walnego piotrkowskiego 1562-1563: „statuimus de consilio omnium ordinum Regni, quod nemo huiusmodi arendas facere aut petere audeat...”; s. 150 - uniwersał poborowym sejmu walnego warszawskiego 1563-1564, oraz s. 188 - uniwersał poborowy sejmu walnego piotrkowskiego 1565; s. 208 - uniwersał poborowy sejmu walnego piotrkowskiego 1567; s. 260 - uniwersał poborowy sejmu walnego lubelskiego 1569; s. 293 - uniwersał poborowy sejmu walnego warszawskiego 1570; s. 314 - uniwersał poborowy sejmu elekcyjnego 1573; s. 400 - uniwersał poborowy sejmików generalnych 1577: „czopowe wszelakie naimowane być nie ma, ani się żaden ktoregokolwiek stanu wolnościami od niego szczycić ma [...]”. 
w przypadku szosu. Ważne było uzyskanie konkretnej kwoty pieniędzy. Wybieranie podatków „wedle osiadłości” oznaczało dla administratorów systemu skarbowego brak pewności co do ostatecznej kwoty wpływów podatkowych, a obserwacja danych zawartych w sumariuszach dawała wręcz pewność spadku dochodów rok do roku. Natomiast przejście do wybierania podatku wedle „starych kwitów” bez abjurat, czy też jego dzierżawienie, dawało nadzieję otrzymania założonych kwot pieniędzy. Tak więc fakt wybierania podatków według „osiadłości” lub według „starych kwitów” niekoniecznie musi być dowodem na (odpowiednio) sprawność lub niesprawność działania systemu podatkowego, lecz po prostu przejawem posługiwania się przez poszczególnych administratorów tego systemu innymi technikami intensyfikowania dochodów skarbowych. Oczywiście w praktyce wyglądało to o wiele gorzej i skarb nadal borykał się z problemem mniejszych dochodów niż zakładane, ale starano się sobie radzić z tym poprzez przede wszystkim uchwalanie wielokrotności poborów lub też poprzez nakładanie nowych podatków ${ }^{54}$.

Podsumowując, możemy więc stwierdzić, że po pierwsze, sumariusze poborowe pojawiły się na przełomie lat 20. i 30. XVI w. w bardzo newralgicznym momencie funkcjonowania aparatu skarbowego Królestwa Polskiego, kiedy to mocno wzrosło zapotrzebowanie na pieniądze na utrzymanie stałej armii, koniecznej do zapewnienia obrony południowych granic Królestwa.

Po drugie, pierwotnym przeznaczeniem sumariuszy było tworzenie dokumentacji niezbędnej do analizy poziomu ściagalności podatków i planowania przyszłych wpływów budżetowych przez podskarbiego, do którego to celu rzeczywiście służyły, na co wskazuja zachowane do dziś sumariusze zbiorcze.

Po trzecie, korzystając z okazji, poborcy zaczęli używać sumariuszy w sprawozdawczości sejmowej w miejsce kwitacji, co ostatecznie zostało zaakceptowane przez administrację centralną. Zarazem jednak utrzymano obowiązek przechowywania kwitacji przez poborców jako narzędzia umożliwiającego przeprowadzenie potencjalnej weryfikacji rzetelności ściagania podatków. Temu samemu samemu służyły też rekognicje.

Po czwarte, w całym analizowanym okresie (a zwłaszcza w latach 60 . XVI stulecia) administracja skarbowa podejmowała wysiłki zmierzające do zwiększenia dochodów skarbowych. Starano się przede wszystkim uszczelnić system poboru podatków zarówno poprzez stymulowanie poborców do zintensyfikowania wysiłków i eliminowanie nadużyć z ich

\footnotetext{
${ }^{54}$ A. Filipczak-Kocur, dz. cyt., s. $69-191$.
} 
strony (próba wprowadzenia systemu niezależnej weryfikacji przychodów skarbowych za pośrednictwem struktur kościelnych w 1527 r.; publiczne zestawianie ze sobą wpływów z kilku poborów w 1565 r.; zakazywanie dzierżawy czopowego), jak i poprzez likwidowanie luk w przepisach umożliwiających unikanie opodatkowania (wprowadzenie dat na rekognicjach i kwitacjach). Dużo rzadziej szukano rozwiązania problemu w nakładaniu nowych podatków, chociaż paradoksalnie to właśnie ten typ działań dawał widoczne wzrosty dochodów skarbowych.

Po piąte wreszcie, po okresie dwóch pierwszych bezkrólewi, wraz z nastaniem panowania Stefana Batorego mamy do czynienia z początkiem przemiany w filozofii działania systemu skarbowego. Zamiast intensyfikowania działań kontrolnych i dyscyplinowania administracji skarbowej, zaczęto przechodzić do systemu, w którym najważniejszym celem było pozyskanie odpowiedniej kwoty pieniędzy, podczas gdy sposób stawał się mniej istotny. Objawiło się to powrotem do praktyki dzierżawienia czopowego, począwszy od 1578 r., i ostatecznie przejściem do wybierania poboru ziemskiego w oparciu o „stare kwity” za panowania Zygmunta III Wazy.

\section{Krzysztof Boroda}

Who needed tax records in the 16th century and why? On budget planning at the start of the early modern period in Poland

\section{(Summary)}

The modern methods of calculating income and expenses using statistical data is sometimes attributed to the period of the Enlightenment. However, an analysis of the surviving sources (constitutions passed by the Sejm and registers of taxable income) suggests that the first attempts to create a balanced budget in the Kingdom of Poland can be dated between 1530-80. At that time action was taken to improve the functioning of the treasury, accompanied by the creation of new types of treasury documentation: tax returns and income tax registers. Both the form and content of the income tax registers indicate that they were used to calculate future years' tax inflows and to seek the reasons for the periodical drops in revenue. Discontinuing the preparation of tax registers at the end of the 16th century was probably related to changes in the rules for preparing the state budget, which manifested itself in calculating lump-sum taxes or leasing out their collection. In place of planning the future budget, the treasury administration began to concentrate mainly on satisfying current state requirements and paying tax arrears.

Key words: early modern history, taxation system, taxes, history of the State, history of law 